\title{
Prospective of biodiesel production utilizing microalgae as the cell factories: A comprehensive discussion
}

\author{
Narendra Mohan Verma, Shakti Mehrotra*, Amitesh Shukla and Bhartendu Nath Mishra \\ Department of Biotechnology, Institute of Engineering and Technology, U.P. Technical University, Sitapur Road, \\ Lucknow - 226021, India. \\ Accepted 30 December, 2009
}

\begin{abstract}
Microalgae are sunlight-driven miniature factories that convert atmospheric $\mathrm{CO}_{2}$ to polar and neutral lipids which after esterification can be utilized as an alternative source of petroleum. Further, other metabolic products such as bioethanol and biohydrogen produced by algal cells are also being considered for the same purpose. Microaglae are more efficient than the conventional oleaginous plants in capturing solar energy as they have simpler cellular organization and high capacity to produce lipids even under nutritionally challenged and high salt concentrations. Commercially, microalgae are cultivated either in open pond systems or in closed photobioreactors. The photobioreactor systems including tubular bioreactors, plate reactors and bubble column reactors have their own advantages as they provide sterile conditions for growing algal biomass. Besides, other culture conditions such as light intensity, $\mathrm{CO}_{2}$ concentration, nutritional balance, etc, in closed reactors remain controlled. On the other hand, though the open ponds provide a cost-effective option to utilize natural light facility for algal cells, the tough maintenance of optimal and stable growth conditions makes it difficult to manage the economy of the process. Further, these systems are much more susceptible to contamination with unwanted microalgae and fungi, bacteria and protozoa that feed on algae. Recently, some work has been done to improve lipid production from algal biomass by implementing in silico and in vitro biochemical, genetic and metabolic engineering approaches. This article represents a comprehensive discussion about the potential of microalgae for the production of valuable lipid compounds that can be further used for biodiesel production.
\end{abstract}

Key words: Biodiesel, fatty acid, lipids, microalgae, triacylglycerol.

\section{INTRODUCTION}

Mankind's continuous use of fossil fuels is unsustainable as they are limited resources of energy (Srivastava and Prasad, 2000) and their combustion will lead to generation of the energy-related emissions of green house gases (GHG) like carbon dioxide, nitrogen oxides, methane, sulfur dioxide and volatile organic compounds (Gavrilescu and Chisti, 2005). During the past few decades, global atmospheric concentrations of GHG

\footnotetext{
${ }^{*}$ Corresponding author. E-mail: shaktimehrotra22gmail.com. narendra_106@yahoo.com._anush.elegant@gmail.com. profbnmishra@gmail.com. Tel: +919450713480.
}

Abbreviations: GHG, green house gases; DCW, dry weight biomass; TG, triacylglycerides; DOE, department of energy; ASP, aquatic species programme; acc, acetyl-CoA carboxilase gene; $\mathbf{R} \& \mathbf{D}$, research and development. have frequently risen with a growth rate of $\mathrm{CO}_{2}$ emissions. Thus, increasing $\mathrm{CO}_{2}$ concentration is considered to be one of main causes of global warming. The combustion of fossil fuels is responsible for $73 \%$ of the $\mathrm{CO}_{2}$ production. As concern about global warming and dependence on fossil fuels grows, the search for renewable energy sources that reduce $\mathrm{CO}_{2}$ emissions becomes a matter of widespread attention (Ragauskas et al., 2006; Demirbas and Demirbas, 2007).

In recent years, cultivation of microalgae has received renewed attention on account of their utility as a feasible $\mathrm{CO}_{2}$ sequestration technology (Ono and Cuello, 2006; Hsueh et al., 2007; Jacob-Lopes et al., 2008). Though the idea of using microalgae to exploit the $\mathrm{CO}_{2}$ emissions from stationary combustion source is not new (Kadam, 1997; Sheehan et al., 1998), a number of studies have been carried out from time to time for the determination of microalgal ability to hold up the high $\mathrm{CO}_{2}$ concentrations 


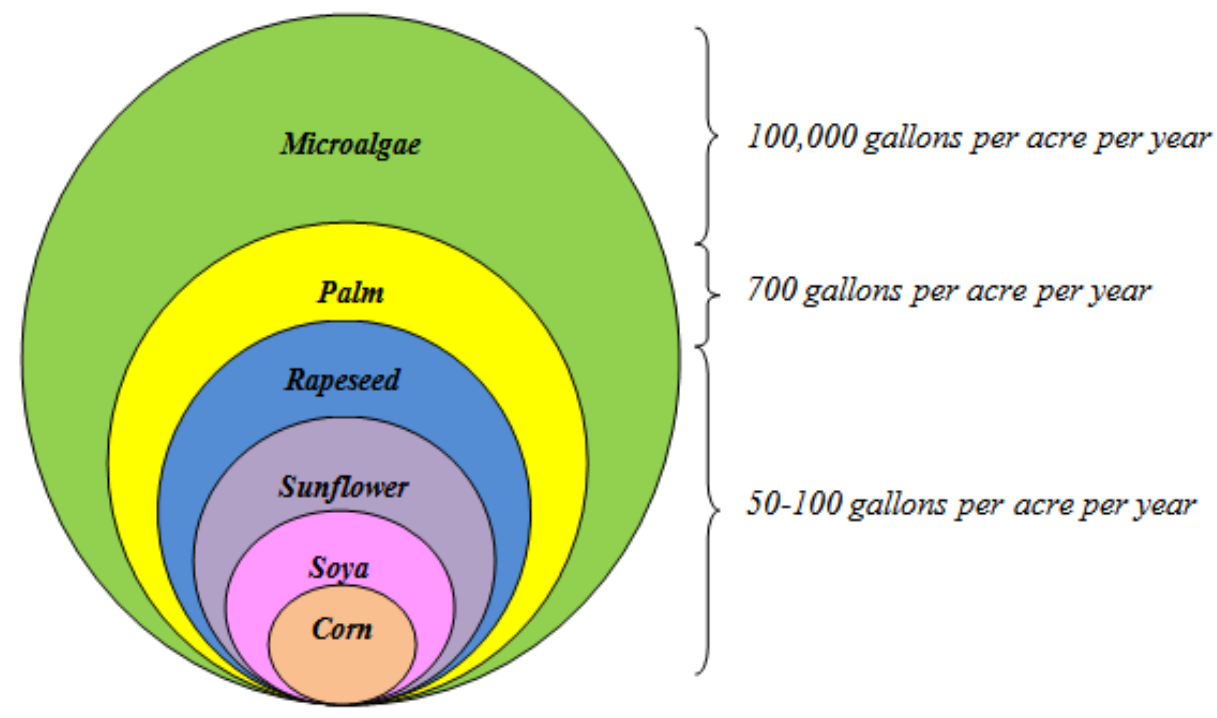

Figure 1. Oil content in microalgae and conventional crops.

and potentially toxic associated $\mathrm{SO}_{x}$ and $\mathrm{NO}_{x}$ gases that are present in fuel gas (Yun et al., 1997; Lee et al., 2002). Microalgal species upon exposure to sunlight are capable of fixing $\mathrm{CO}_{2}$ to produce biofuel and other chemical compounds. These are the miniature sunlight driven biochemical factories and some of the most efficient $\mathrm{CO}_{2}$ fixers on this planet. The $\mathrm{CO}_{2}$ fixation in these cells leads to the formation of lipids which after esterification with methanol produce biodiesel. After extracting oil from microalgae, the remaining biomass portion can also be used as a high protein feed for livestock (Schneider, 2006; Haag, 2007). This gives additional value to the process and endow with an overall economical feasibility. Commercial-scale cultivation of microalgal biomass is a promising method of producing a renewable feedstock for a wide variety of high-value biofuels. It include methane produced by anaerobic digestion of biomass (Spolaore et al., 2006), biodiesel derived from oil (Banerjee et al., 2002; Gavrilescu and Chisti, 2005), biohydrogen and bioethanol produced by photobiologically active microalgae (Fedorov et al., 2005; Kapdan and Kargi, 2006). The present article expresses the potential of microalgae cultivation for biodiesel production and discusses the utilization of recent engineering techniques for enhancement of lipid profiles in important microalgal strains to make the process more economic and practically feasible.

\section{CONSIDERING MICROALGAE ADVANTAGEOUS OVER OTHER OLEAGINOUS CROPS}

Advantages of microalgal cultivation for biodiesel production have been extensively discussed in a number of scientific and non-scientific articles. Comparing microalgae with other oleaginous crops, the formers are not only easy to handle and more beneficial from economic point of view but also known for their bioremediation capabilities (Dayananda et al., 2005; Sazdanoff, 2006; Chisti, 2007; Huntley and Redalje, 2007; Li et al., 2008; Schenk et al., 2008; Tan et al., 2009). Some positive points of microalgal cultivation are succinctly being given in upcoming text.

i. Simple cellular structure and ability to control cell composition without decreasing productivity.

ii. High photosynthesis yields, that is, about $3-8 \%$ of solar energy can be converted to biomass as compared to terrestrial plants where it is approximately $0.5 \%$.

ii. Ability to bloom on carbon dioxide from gas and coalfired power plants.

iv. Short life cycle (approximately 1 - 10 days).

v. Ability to synthesize and accumulate large quantities of lipids per dry weight biomass (DCW) $(40-86 \%)$.

vi. Potential to grow in saline water and harsh conditions.

vii. Lesser fertilizer and nutrient input requirements.

viii. Most convincing non-food source of biodiesel.

ix. Capable to grow in controlled conditions of specially designed bioreactors throughout the year and;

$x$. Potential to produce $10-20$ times higher yield of oil compared to other oleaginous seeds and/or vegetable oils (Figure 1 ).

\section{THE FATTY ACIDS BIOCHEMISTRY OF MICROALGAE}

The microalgal community possesses a favorable fatty acids profile that can be utilized for biodiesel production with high oxidation stability. The physical and chemical (fuel) properties such as density, viscosity, acid value, heating value, etc, of biodiesel from microalgae oil are 
Table 1. Microalgae species considered for oil production.

\begin{tabular}{|l|l|l|}
\hline \multicolumn{1}{|c|}{ Algal strains } & \% lipid in DCW & \\
\hline Anabaena cylindrica & $4-7$ & Recker, 1994 \\
Ankistrodesmus species & $28-40$ & Ben-Amotz and Tornabene, 1985 \\
Botryococcus braunii & $25-86$ & Dayananda et al., 2005 \\
Chaetoceros muelleri & 24.4 & Mohapatra, 2006 \\
Chlamydomonas species & 23 & Feinberg, 1984 \\
Chlorella emersonii & 63 & Gouveia and Oliveira, 2009 \\
Chlorella minutissima & 57 & Gouveia and Oliveira, 2009 \\
Chlorella protothecoides & $15-55$ & Xiong et al., 2008 \\
Chlorella sorokiana & 22 & Gouveia and Oliveira, 2009 \\
Chlorella vulgaris & $14-56$ & Gouveia and Oliveira, 2009 \\
Cyclotella species & 42 & Sheehan et al., 1998 \\
Dunaliella bioculata & 8 & Becker, 1994 \\
Dunaliella salina & 28.1 & Mohapatra, 2006 \\
Dunaliella tertiolecta & $36-42$ & Tsukahara and Sawayama, 2005 \\
Hantzschia species & 66 & Sheehan et al., 1998 \\
Isochrysis galbana & 21.2 & Mohapatra, 2006 \\
Monallantus salina & 72 & Shifrin and Chisholm, 1981 \\
Nannochloropsis species & 28.7 & Gouveia and Oliveira, 2009 \\
Neochloris oleoabundans & $35-65$ & Tornabene et al.., 1983 \\
Nitschia closterium & 27.8 & Mohapatra, 2006 \\
Nitschia frustulum & 25.9 & Mohapatra, 2006 \\
Phaeodactylum tricornutum & $20-30$ & Molina Grima et al., 2003; Fernandez et al., 2003; Chisti, 2007 \\
Scenedesmus dimorphus & $16-40$ & Becker, 1994 \\
Scenedesmus obliquus & $12-14$ & Becker, 1994 \\
Scenedesmus quadricauda & 19.9 & Mohapatra, 2006 \\
Selenastrum species & 21.7 & Mohapatra, 2006 \\
Skeletonema costatum & 19.7 & Mohapatra, 2006 \\
Spirulina maxima & $6-7$ & Becker, 1994 \\
Spirulina plantensis & 16.6 & Feinberg, 1984 \\
Stichococcus species & 33 & Sheehan et al., 1998 \\
Tetraselmis maculata & 3 & Becker, 1994 \\
Tetraselmis suecia & $15-23$ & Chisti, 2007; Huntley and Redalje, 2007 \\
\hline
\end{tabular}

very much comparable to those of fuel diesel (Miao and $\mathrm{Wu}, 2006)$. The lipids are produced in algal cells as they utilize both inorganic $\left(\mathrm{CO}_{2}\right.$ from atmosphere) and organic form of carbon (energy substrate from growing ambience). Various classes of lipids (both polar and neutral) such as triglycerides, phospholipids, cholesterol, etc, are produced among which triglycerides are the major raw lipid precursor for biodiesel production. A list of different algal species capable of biodiesel production from their lipid content is given in Table 1. Triglyceride biosynthesis is conveniently divided into three steps: (i) formation of Acetyl CoA; (ii) acyl chain elongation and finally (iii) triacylglycerol (TG) formation (Figure 2) (Hu et al., 2008; Courchesne et al., 2009; Huang et al., 2009). The oil extracted from microalgae is subjected to transesterification reaction to obtain biodiesel (Figure 3).

In microalgae, greater variation in the fatty acids chain composition depending upon species to species is

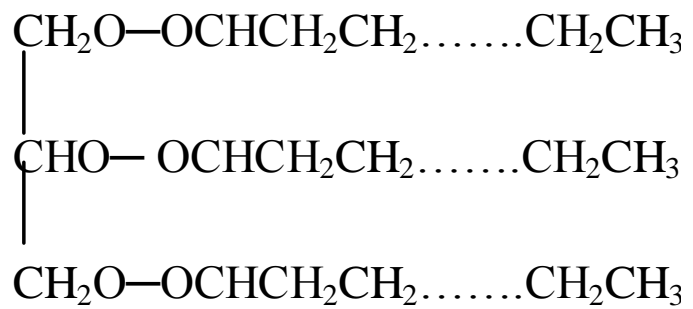

Figure 2. Molecular structure of triacylglycerol (TAG).

observed. Fatty acids chain may be saturated or unsaturated and the unsaturated fatty acids can differ in the number and position of double bonds on carbon chain backbone (Borowitzka, 1988). In favorable conditions of growth, fatty acids chain length include medium-chain 


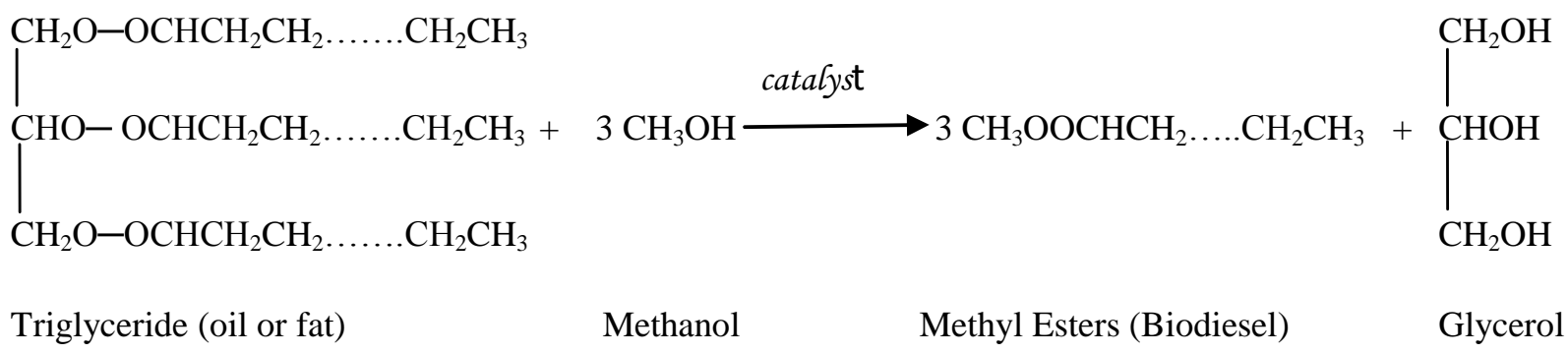

Figure 3. Transesterification reaction to produce biodiesel.

(C10-C14); recognized in Trichodesmium erythraeum (C10) and Prymnesium parvum (C14) (Parker et al., 1967; Lee and Loeblich, 1971), long-chain (C16-18) and very-long-chain ( $\geq \mathrm{C} 20$ as observed in Parietochloris incise, Phaeodactylum tricornutum (C20) and Crypthecodinium cohnii (C22), respectively (De Swaaf et al., 1999; Bigogno et al., 2002). The major synthesized fatty acid chain length ranges from $\mathrm{C} 16$ to $\mathrm{C} 18$, which are identical to conventional oleaginous crops (Ohlrogge and Browse, 1995).

Hydrocarbons are another category of neutral lipids that can be present in microalgae at quantities typically $<5 \%$ DCW. The green colonial unicellular Botryococcus braunii, in unfavorable conditions, has been observed to have high amount of hydrocarbons that is up to $25-86 \%$ in DCW (Dayananda et al., 2005), similar to those that occur in petroleum, and thus has been explored as a feedstock for biodiesel. The hydrocarbon synthesizing and accumulating ability of alga varies at different growth phase in different culture conditions. The maximum productivity occurs in exponential and early stationary growth phases followed by an increase in unsaponifiable lipid content up to $80 \%$ DCW.

\section{COMMERCIAL-SCALE MICROALGAE}

\section{CULTIVATION OF}

The economic biodiesel production from microalgae requires enormous bulk of algal biomass. Practically, convenient commercial-scale production of algal biomass can be achieved by two feasible methods (i) Conventional open ponds systems and (ii) Closed photobioreactors (Patil et al., 2005; Carvalho et al., 2006).

\section{Open ponds system}

The large-scale cultivation of microalgae is usually located outdoors open pond systems and relies on natural light for illumination. Thus, setting up, operating and maintenance cost is less as compared to bioreactors. The most common strains used for the cultivation of biomass in open ponds system are- Anabaena, Chlorella, Dunaliella, Haematococcus, Nostoc and Spirulina (Chisti, 2006). The open ponds have a variety of shapes and sizes depending upon the location of cultivation, however, the most frequently used designs for the culture of algal biomass are raceway ponds and circular ponds. An assessment of open ponds for algal cultivation by the United States Department of Energy (DOE) (Sheehan et al., 1998) suggested that such ponds should have standard dimensions of $10 \mathrm{~m}$ width, $100 \mathrm{~m}$ length and $30 \mathrm{~cm}$ depth built in concrete blocks, on a 10 $\mathrm{cm}$ thick sole for optimized biomass growth. A paddle wheel (raceway systems) or a rotating arm (circular systems) which can be usually operated at water depths of $10-20 \mathrm{~cm}$ for culture agitation, mixing and preventing the material from settling on the bottom (Richmond, 2003; Chisti, 2007). Maximum biomass productivity is attained under tropical or subtropical conditions (Jimenez et al., 2003). An algal biomass productivity achieved in open pond systems may range between 10 to $50 \mathrm{gm}^{-2} \mathrm{~d}^{-1}$ (Sheehan et al., 1998) irrespective of raceway or circular ponds. Though the growth-rates and productivity observed in open ponds are usually lower than the photobioreactors, the formers are economically more favorable due to lower establishment cost. The disadvantages of open systems include the issues of land use cost, water availability and appropriate climatic conditions since it is more difficult to maintain optimal and stable growth conditions in an open pond (Chisti, 2007; Haag, 2007). Another limitation of open ponds is that by being open to the atmosphere, they lose water by evaporation at a rate similar to terrestrial crops. Moreover, due to direct exposure these systems are also susceptible to contamination with unwanted microalgae and fungi, bacteria and protozoa that feed on algae.

\section{Closed Photobioreactors}

Commercial-scale cultivation of microalgal biomass in photobioreactors is more successful. Photobioreactors are the closed culture system and preferred over open ponds as they can be established and maintained either indoor or outdoor (Pulz, 2001). But, the outdoor 
establishment is more successful because they can utilize free sunlight. Basically, these bioreactors allow for the cultivation of single microalgal species for prolonged duration under controlled conditions (Carvalho et al., 2006). Number of species such as Cyclotella cryptica, Monoraphidium minutum and Tetraselmis suecica has been successfully grown in closed photobioreactors for various purposes (Huntley and Redalje, 2007).

Several types of photobioreactors exist for the cultivation of algal biomass (Sanchez Miron et al., 2000; Pulz, 2001; Acien Fernandez et al., 2001, 2003; Muller-Feuga et al., 2003). These include widely used tubular photobioreactors, plate reactors, bubble column reactors and less commonly used semi-hollow-spheres (Sato et al., 2006). Tubular photobioreactors consist of transparent array tubes made up of glass and plastics and have strong and stable transmission of light intensity in the photosynthetically active range. These solar collector tubes are usually 0.01 to $0.1 \mathrm{~m}$ in diameter and fixed generally in the north-south direction to enable the maximum light to penetrate the suspended cells into a significant amount (Grima et al., 1999). The floor beneath the solar collector is either painted white or covered with white sheets of plastic to increase reflection, thus enhances the total intensity of light received by an array tube (Chisti, 2007). The inflow of microalgal inoculam and fresh culture medium is maintained at a constant rate. Mixing in reactors is important to prevent sedimentation of cells and even distribution of gases. The closed photobioreactors are advantageous in the way that they remain free from contamination for prolonged periods and also provide suitable environmental conditions such as $\mathrm{CO}_{2}$ concentration, nutritional balance due to proper mixing of growth medium, $\mathrm{pH}$, temperature and light intensity. Maximum productivity can be achieved by optimizing these culture conditions. The major drawback with these reactor systems is that they have more building and operating cost.

\section{FACTORS INFLUENCING MICROALGAL GROWTH}

Although the TG producing capability of microalgal cells is genetically controlled, the quantity and quality of oils produced by algal cell is directly proportional to the stimulus received from surroundings. The major environment stimulus that govern mass growth concomitant with oil production include carbon dioxide, water, nutrients deficit, light intensity, $\mathrm{pH}$ and temperature (Borowitzka, 1999). The optimized ambience makes best use of these miniature factories to maximize the oil production irrespective of cultivation system.

\section{Carbon dioxide}

The microalgae are ten times more efficient in biological fixation of atmospheric $\mathrm{CO}_{2}$ than terrestrial plants (Usui and Ikenouchi, 1997) and this efficiency is highly variable with various species and observed as low as $0.26 \mathrm{mg}$ $\mathrm{CO}_{2} \mathrm{~m}^{-3} \mathrm{~h}^{-1}$ (Cheng et al., 2006) to high mitigation of 1.33 $\mathrm{g} \mathrm{CO}_{2} \mathrm{~m}^{-3} \mathrm{~h}^{-1}$ (Hirata et al., 1996). The only carbon source in the cultivation of microalgae is $\mathrm{CO}_{2}$. Thus, the $\mathrm{CO}_{2}$ input cost plays a vital role in the economy of biodiesel production. In order to optimize the microalgal growth, $\mathrm{CO}_{2}$ needs to be provided at much high concentration and this concentration can be attained under natural conditions (Pulz, 2007). Those areas should be investigated which have high $\mathrm{CO}_{2}$ concentration and these sites can be used by both raceway ponds and photobioreactors for the cultivation of microalgae (Schneider, 2006). Flue-gases from steel industries and thermal power plants contain much more $\mathrm{CO}_{2}$ concentration than that of normal air; selecting and screening of high $\mathrm{CO}_{2}$ tolerant algal strains before adopting for commercial cultivation is one of the best strategies to improve the practical feasibility of the process from economic point of view.

\section{Water and nutrient}

Growing microalgal cells get essential nutrition from water in which they grow. Water is usually occurring in treated or untreated livestock wastewater and they can be reprocessed to conserve resources as well as to reduce the culture medium cost. Conclusively, algae need not compete with other users for fresh water and cultivating algal mass by utilizing wastewater can be considered as biological remediation phenomenon under wastewater management. Extensive studies have been carried out by using wastewater for the cultivation of algal biomass, especially for the removal of nitrogen and phosphorus salts from effluents (Hernandez et al., 2006; Abdel-Hameed, 2007; Shi et al., 2007), which would otherwise result in eutriphication if dumped into lakes and river (Galvez-Cloutier et al., 2006). In addition to nitrogen and phosphorus removal, other studies have also conducted for the removal of heavy metals from wastewater (Munoz and Guieysse, 2006; Priya et al., 2007; Singh et al., 2007). The algal cells effectively grow in both fresh and saline water having salt concentrations up to twice that of seawater (Aresta et al., 2005). Dunaliella salina can grow in salinity levels higher than $200 \mathrm{~g} \mathrm{NaCl}$ $\mathrm{L}^{-1}$ and Spirulina platensis can grow in highly alkaline medium with a pH up to 10 (Huntley and Redalje, 2007). The in vitro studies on effect of salinity on growth of green alga Botryococcus braunii and its constituents reveal reduction in biomass and total protein content due to lowering of photosynthetic rate but the major difference was observed in fatty acid profile especially in the relative proportions of stearic, linoleic, palmitic and oleic acids (Ranga Rao et al., 2007).

The consequence of nitrogen deprivation was inves- 
tigated on lipid metabolism and signification alteration in lipid or fatty acid content is reported in various species including Anacystis nidulans, Microcystis aeruginosa, Oscillatoria rubescens and Spirulina platensis (Basova, 2005). Generally, nitrogen deficiency greatly affects the synthesis and accumulation of lipids and fatty acid (Saha et al., 2003). Phosphorus deficiency resulted into the enhancement of lipid in Monodus subterraneus (KhozinGoldberg and Cohen, 2006), Chaetoceros species, Isochrysis galbana, Pavlova lutheri and Phaeodactylum tricornutum, but decreases the lipid content of Nannochloris atomus and Tetraselmis species (Reitan et al., 1994). Silicon deprivation resulted in increased neutral lipids content of Cyclotella cryptica and increased quantity of saturated and mono-unsaturated fatty acids than cells grown on silicon rich ambience (Roessler, 1988). Scarcity of sulfur was also investigated in Chlamydomonas reinhardtii (Sato et al., 2000) and Chlorella species (Otsuka, 1961) and resulted the enhancement of total lipid contents.

\section{Selection of strains}

To maintain the cost effectiveness of commercial biodiesel production, the selection of appropriate strain according to the site of cultivation is imperative. The species that are high salt tolerant, high $\mathrm{CO}_{2}$ tolerant and even able to grow and reproduce under nutritional scarcity by altering their metabolic pathways efficiently found most promising in this regard. A list of more than 300 microalgal species is declared by Aquatic Species Programme (ASP) of U.S. DOE representing a diversity of aquatic environments and water types. These species were screened on the bases of vigor, oil content, growth rate and metabolic efficiency under different environmental conditions (Sheehan et al., 1998).

\section{Light intensity}

Microalgae are able to grow under different intensities of light. However only high light intensities favor the bioproduction of neutral storage lipids mainly TG. In contrast, polar lipids are formed under low amount of light. About $45 \%$ of the total light spectrum consists of photosynthetically active radiation, thus can be utilized by algal flora to capture $\mathrm{CO}_{2}$ (Gao et al., 2007). Light gets absorbed by the algae, so the higher the algae concentration, the less deep light enters into the broth. Therefore, optimization of shape and size of growth container is critical for grasping of light by algal biomass, as much as possible. Sunlight is available in different quantities in different geographical locations. Open ponds systems should be placed in those regions where the receiving of sunlight is abundant and uninterrupted. In photobioreactors, sunlight intensity can be improved through the use of solar collectors, solar concentrators and fiber optics (Scott and Bryner, 2006; Chisti, 2007). However, to reduce the economic cost of the biodiesel production, algal biomass may be grown by utilizing the freely accessible sunlight.

\section{Temperature}

Temperature has been found to have a major effect on the fatty acid composition of algae. A general trend towards increasing fatty acid unsaturation with decreasing temperature and increasing saturated fatty acids with increasing temperature has been observed in many algae (Renaud et al., 2002). The lipid content in Ochromonas danica (Aaronson, 1973) and Nannochloropsis salina (Boussiba et al., 1987) increases with increasing temperature. But, no significant change observed in the lipid content in Chlorella sorokiniana grown at various temperatures (Patterson, 1970). Insight information about the effect of temperature on lipid synthesis and accumulation in microalgae is still required to explore.

\section{RECOVERY OF PRODUCT}

\section{Harvesting method}

Harvesting includes the removal of heavy water content and extraction of oil from algal biomass. There is no such single method that can be applied for harvesting and removing their water content. Harvesting costs may contribute $20-30 \%$ to the total cost of oil production through algal biomass (Grima et al., 2003). In microalgal aquaculture, the conventional processes used to harvest include flocculation (Knuckey et al., 2006), concentration through centrifugation (Heasman et al., 2000), foam fractionation (Csordas and Wang 2004), filtration (Rossignol et al., 1999) and ultrasonic separation (Bosma et al., 2003).

Flocculation is applied to create congregation of microalgae mass so that it can easily be removed from water. The technique may be biological flocculation where, microalgae cells start accumulating themselves, forming flocks due to the presence of non algal microbial entity or it may be chemical flocculation in which certain chemicals such as aluminum sulfate, chitosan, ferric chloride and ferric sulfate are used to promote the formation of flocks. Both types of flocculation methods are usually followed by sedimentation, filtration or centrifugation. The sedimentation of microalgal biomass though, an effective technique but not suitable in oil production as it is space and time consuming thereby severely affect the overall cost of the procedure. Besides, centrifugation is efficiently used to recover microalgae in large volumes but here also the use of electrically or 
mechanically driven centrifuge makes this procedure too costly. Filtration is carried out under pressure or vacuum if algae sizes do not approach bacteria sizes. Microstrainers (typically 25 to $50 \mu \mathrm{m}$ openings) can be used for species like Anabaena or Spirulina, which are filamentous in shape. If flocculation is performed before, higher filtration efficiency will be reached (Sheehan et al., 1998; Grima et al., 2003). On the whole, selection of harvesting method depends upon the type of algal species, volume and size of pond, etc (Schenk et al., 2008).

\section{Lipid extraction and transesterification}

Collection of cell biomass is followed by oil extraction simply which is done through cell disruption through mechanical crushing. However now a days the more delicate method is being utilized where perforation of algal cell wall is done subjecting the mass under high electric field. This is known as electroporation. Extracted oil when subjected to trans-esterification using methanol and a catalyst such as sodium methoxide results in the production of biodiesel (Figure 3) (Fukuda et al., 2001).

\section{INNOVATIVE APPROACHES FOR ENHANCED BIODIESEL YIELD}

Utilizing current approaches for the enhanced lipid profiles in microalgae is the present day's scenario. Involvement of engineering aspects at biochemical and genetic level can be considered as a potent strategy for this purpose (Courchesne et al., 2009). The biochemical studies for increased lipid biosynthesis were being emphasized from last decade when ASP center of U.S. DOE focused to increase the lipid synthesis under nutrient stress conditions in algal species (Dempster and Sommerfeld, 1998) and such studies showed that growing microalgae under nutrient stress is most established strategy for enhanced lipid production. In algal growth, nutritional deficiency is the major factor which is responsible for the flux balance of primary metabolites. Extensive studies on different genera such as Botryococcus, Chlorella, Monodu, Neochloris have been done in this regard that revealed that nutritionally challanged photosynthetically active algal community directs its metabolism towards lipid biosynthesis and accumulation (Illman et al., 2000; Shastri and Morgan 2005; Zhila et al., 2005; Khozin-Goldberg and Cohen, 2006; Boyle and Morgan, 2009). Nitrogen and phosphorus are the two major nutrients, starvation of which lead to lipid accumulation in various algal communities. Additionally, other stress conditions including high salinity, excessive low or high temperatures and variations in $\mathrm{pH}$ are also found to be controlling factors that govern the channeling of metaboliite flux from starch to lipids (Takagi et al., 2006).

A major limitation in dealing with nutrient stress challenged algal cultivation is that scarcity of such important elements leads to an undesired effect on cell biomass growth as these elements are required for overall cellular activities including cell division and photosynthesis. This generally results in lowering of biomass and subsequently in total lipid content (Li et al., 2008; Scragg et al., 2002).

The two stage cultivation technique is applied to resolve this constraint up to an extent where in the first stage, the cells are subjected or enabled to grow and amplify in a nutrient rich medium and then in the second stage where algal cells face specific nutrient depletion or any other stress so that lipid accumulation is triggered ( $\mathrm{Li}$ et al., 2008; Huntley and Redalje, 2007).

Genetic and metabolic engineering in microalgae for biodiesel production is a blooming strategy where introduction and expression of genes encoding rate limiting enzyme of lipid biosynthetic pathway are concerned. By the advent of complete genome sequence of different microalgal species such as Anabaena, Ostreococcus tauri, Thalassiosira pseudonana and other higher algal species (Armbrust et al., 2004; Derelle et al., 2006; Bowler et al., 2008; Beer et al., 2009), the genetic transformation of microalgal species for various purposes is now being a routine practice. Emphasizing the genetic transformation in microalga for biodiesel production there is a particular relevance of example of transformation of Cyclotella cryptica and Navicula saprophila with acetylCoA carboxilase (acc) gene (Dunahay et al., 1996; Sheehan et al., 1998) initially isolated from Cyclotella cryptic (Roessler, 1990). Though the enhanced activity revealed that acc was successfully expressed but no lipid content was increased in transgenics. This suggested that regulation on acc activity alone is not enough for increased lipid biosynthesis and accumulation. However such kinds of studies have opened an array of research in genetic engineering of microalgal cells for enhanced lipid production. The insight understanding of various rate limiting steps of lipid biosynthetic pathway (Courchesne et al., 2009), expression and regulatory analysis of genes and enzymes involved in triacylglycerol formation such as acetyl-CoA carboxilase, fatty acid synthase (Dehesh et al., 2001), acyl-CoA: diacylglycerol acyl transferase (Bouvier-Nave et al., 2000; Jako et al., 2001) and of those enzymes that influence TG biosynthesis directly or indirectly such as acetyl-CoA synthase, etc, in transgenics may facilitate the engineering practice in microalgae for enhanced biodiesel production. Further, regulation at transcription level by involving transcription factors to control the overall metabolite flux can also be a considerable strategy for the desired purpose. Transcription factors are the proteins that recognize DNA through specific sequences and bind with them due to DNA-protein interaction leading to controlled expression of DNA sequence. A number of studies is going on worldwide in different plant systems where these transcription regulatory proteins are over-expressed to up or down regulate the concerned pathways that ultimately lead to overproduction of secondary metabolite of interest. Though 
implementation of above discussed aspects of regulatory genomics approach for enhanced lipid biosynthesis and accumulation in microalgae is in its infancy yet this is the concept which may prove promising in long term future perspectives.

\section{Conclusion}

The atmospheric unevenness arising due to increase in atmospheric $\mathrm{CO}_{2}$ concentration coupled with depletion of mineral oil reserves is constantly producing troublesome situations. Exploitation of microalgal biomass cultivation is not only beneficial for $\mathrm{CO}_{2}$ fixation but also results in the bioproduction of triglycerides which after esterification with methanol get converted into biodiesel. Thus biodiesel produced from renewable and often microalgae sources, represents a more sustainable source of energy and will therefore play an increasingly significant role in providing the energy requirements for transportation. The technical and economic feasibility in microalgal biodiesel production makes this process suitable for wide acceptance. Biodiesel are also likely to have much lower impacts on the environment and the world's food supply than conventional biodiesel producing crops. The main reasons for this are high yields, a near-continuous harvest stream and the potential to site the algal bioreactors on non-agriculturable land. The major challenge over the next few years in microalgal biodiesel area is the improvement of lipid profiles of various important strains. Enhancement in lipids bioproduction in microalgal cells by providing stress challenge and altering the biosynthetic pathways is a promising strategy (Boyle and Morgan, 2009). However, nutritionally stressed algal populations show lower growth rate and low protein content especially in nitrogen low growth medium. The genomics and metabolomic approach for metabolic flux management is the emerging concept that can show considerable potential in this area. Identification of rate limiting steps and an in depth study in genetic regulation of concerned genes and enzymes of lipid biosynthetic pathway may prove beneficial for the enhancement of lipid contents at cellular level.

Research on microalgae based biodiesel production is continuing and commercial-scale use of microalgae for biodiesel would require massive investments in production facilities. The $R \& D$ organizations throughout the world should also venture into a project which can explore the biodiesel wealth. This is also necessary to sustain our future needs for energy as well as to enable us to earn the carbon credit by adopting the green-clean technology for biodiesel production.

\section{ACKNOWLEDGEMENTS}

The financial assistance provided in the form Post Doctoral fellowship from DBT, Government of India and GATE fellowship from All India Council of Technical
Education to authors SM, NMV and AS respectively is greatly acknowledged.

\section{REFERENCES}

Aaronson S (1973). Effect of incubation temperature on the macromolecular and lipid content of the phytoflagellate Ochromonas danica. J. Phycol. 9: 111-113.

Abdel-Hameed MS (2007). Effect of algal density in bead, bead size and bead concentrations on wastewater nutrient removal. Afr. J. Biotechnol. 6: 1185-1191.

Acien Fernandez FG, Fernandez Sevilla JM, Sanchez Perez JA, Molina Grima E, Chisti Y (2001). Airlift-driven external-loop tubular photobioreactors for outdoor production of microalgae: assessment of design and performance. Chem. Eng. Sci. 56: 2721-2732.

Acien Fernandez FG, Hall DO, Canizares Guerrero E, Rao K, Molina Grima E (2003). Outdoor production of Phaeodactylum tricornutum biomass in a helical reactor. J. Biotechnol. 103: 137-152.

Aresta M, Dibenedetto A, Carone M, Colonna T, Fagale C (2005). Production of biodiesel from macroalgae by supercritical $\mathrm{CO}_{2}$ extraction and thermochemical liquifaction. Environ. Chem. Lett. 3: 136-139.

Armbrust EV, Berges JA, Bowler C, Green BR, Martinez D, Armbrust EV, Berges JA, Bowler C, Green BR, Martinez D, Putnam NH, Zhou $\mathrm{S}$, Allen AE, Apt KE, Bechner M, Brzezinski MA, Chaal BK, Chiovitti A, Davis AK, Demarest MS, Detter JC, Glavina T, Goodstein D, Hadi MZ, Hellsten U, Hildebrand M, Jenkins BD, Jurka J, Kapitonov VV, Kroger N, Lau WWY, Lane TW, Larimer FW, Lippmeier JC, Lucas S, Medina M, Montsant A, Obornik M, Parker MS, Palenik B, Pazour GJ, Richardson PM, Rynearson TA, Saito MA, Schwartz DC, Thamatrakoln K, Valentin K, Vardi A, Wilkerson FP, Rokhsar DS (2004). The Genome of the diatom Thalassiosira Pseudonana: ecology, evolution, and metabolism. Science 306(5693): 79-86.

Banerjee A, Sharma R, Chisti Y, Banerjee UC (2002). Botryococcus braunii: a renewable source of hydrocarbons and other chemicals. Crit. Rev. Biotechnol. 22: 245-79.

Basova MM (2005). Fatty acid composition of lipids in microalgae. Int. J. Algae 7: 33-57.

Becker EW (1994). Microalgae: Biotechnology and Microbiology. Cambridge University Press, Cambridge, UK.

Beer LL, Boyd ES, Peters JW, Posewitz MC (2009). Engineering algae for biohydrogen and biofuel production. Curr. Opin. Biotechnol. 20(3): 264-271.

Ben-Amotz A, Tornabene TG (1985). Chemical profile of selected species of macroalgae with emphasis on lipids. J. Phycol. 21: 72-81.

Bigogno C, Khozin-Goldberg I, Boussiba S, Vonshak A, Cohen Z (2002). Lipid and fatty acid composition of the green oleaginous alga Parietochloris incisa, the richest plant source of arachidonic acid. Phytochemistry, 60: 497-503.

Borowitzka MA (1988). Fats, oils and hydrocarbons. In Microalgal Biotechnology (Borowitzka MA and Borowitzka LJ, eds). Cambridge University Press, Cambridge, UK, pp. 257-287.

Borowitzka MA (1999). Commercial production of microalgae: ponds, tanks, tubes and fermenters. J. Biotechnol. 70: 313-321.

Bosma R, Van Spronsen WA, Tramper J, Wijffels RH (2003). Ultrasound, a new separation technique to harvest microalgae. J. Appl. Phycol. 15: 143-153.

Boussiba S, Vonshak A, Cohen Z, Avissar Y, Richmond A (1987). Lipid and biomass production by the halotolerant microalga Nanochloropsis salina. Biomass 12: 37-47.

Bouvier-Nave P, Benveniste P, Oelkers P, Sturley SL, Schaller H (2000). Expression in yeast and tobacco of plant cDNAs encoding acyl CoA: diacylglycerol acyltransferase. Eur. J. Biochem. 267(1): 8596.

Bowler C, Allen AE, Badger JH (2008). The Phaeodactylum genome reveals the evolutionary history of diatom genomes. Nature, 456(7219): 239-244.

Boyle NR, Morgan JA (2009). Flux balance analysis of primary metabolism in Chlamydomonas reinhardtii. BMC Syst. Biol. 3: 4.

Carvalho AP, Meireles LA, Malcata FX (2006). Microalgal reactors: A 
review of enclosed system designs and performances. Biotechnol. Prog. 22: 1490-506.

Cheng L, Zhang L, Chen H, Gao C (2006). Carbon dioxide removal from air by microalgae cultured in a membrane-photobioreactor. Sep. Purif. Technol. 50: 324-329.

Chisti $Y(2006)$. Microalgae as sustainable cell factories. Environ. Eng. Manag. J. 5: 261-274.

Chisti Y (2007). Biodiesel from microalgae. Biotech. Adv. 25: 294-306.

Courchesne NMD, Parisien A, Wang B, Lan CQ (2009). Enhancement of lipid production using biochemical, genetic and transcription factor engineering approaches. J. Biotechnol. 141(1-2): 31-41.

Csordas A, Wang JK (2004). An integrated photobioreactor and foam fractionation unit for the growth and harvest of Chaetoceros spp. in open systems. Aquacult. Eng. 30: 15-30.

Dayananda C, Sarada R, Bhattacharya S, Ravishankar GA (2005). Effect of media and culture conditions on growth and hydrocarbon production by Botryococcus braunii. Pro. Biochem. 40: 3125-3131.

De Swaaf ME, de Rijk TC, Eggink G, Sijtsma L (1999). Optimisation of docosahexaenoic acid production in batch cultivation by Crypthecodinium cohnii. J. Biotechnol. 70: 185-192.

Dehesh K, Tai H, Edwards P, Byrne J, Jaworski JG (2001). Overexpression of 3-ketoacyl-acyl-carrier protein synthase IIIs in plants reduces the rate of lipid synthesis. Plant Physiol. 125(2): 11031114.

Demirbas AH, Demirbas I (2007). Importance of rural bioenergy for developing countries. Energy Convers. Manag. 48: 2386-2398.

Dempster TA, Sommerfeld M (1998). Effects of environmental conditions on growth and lipid accumulation in Nitzschia communis (Bacillariophyceae). J. Phycol. 34: 712-721.

Derelle E, Ferraz C, Rombauts S, Rouze P, Worden AZ (2006). Genome analysis of the smallest free-living eukaryote Ostreococcus tauri unveils many unique features. PNAS 103(31): 11647-11652.

Dunahay TG, Jarvis EE, Dais SS, Roessler PG (1996). Manipulation of microalgal lipid production using genetic engineering. Appl. Biochem. Biotechnol. 57-58: 223-231.

Fedorov AS, Kosourov S, Ghirardi ML, Seibert M (2005). Continuous $\mathrm{H}_{2}$ photo-production by Chlamydomonas reinhardtii using a novel twostage, sulfate-limited chemostat system. Appl. Biochem. Biotechnol. 24: 403-412.

Feinberg D (1984). Fuels options from microalgae with representative chemical compositions. Report, Solar Energy Research Institute, Colorado, United States. pp. $10-13$.

Fukuda H, Kondo A, Noda H (2001). Biodiesel fuel production by transesterification of oils. J. Biosci. Bioeng. 92: 405-416.

Galvez-Cloutier R, Leroueil S, Allier D, Locat J, Arsenault S (2006). A combined method: Precipitation and capping, to attenuate eutrophication in Canadian lakes. J. ASTM Int. 3

Gao KS, Wu YP, Li G, Wu HY, Villafane VE, Helbling EW (2007). Solar UV radiation drives $\mathrm{CO}_{2}$ fixation in marine phytoplankton: a double edged sword. Plant Physiol. 144(1): 54-59.

Gavrilescu M, Chisti Y (2005). Biotechnology- A sustainable alternative for chemical industry. Biotechnol. Adv. 23: 471-499.

Gouveia L, Oliveira AC (2009). Microalgae as raw material for biofuels production. J. Ind. Microbiol. Biotechnol. 36: 269-274.

Grima Molina E, Acien Fernandez FG, Garcia Camacho F, Chisti Y (1999). Photobioreactors: light regime, mass transfer and scaleup. J. Biotechnol. 70: 231-247.

Haag AL (2007). Algae bloom again. Nature, 447(31): 520-521.

Heasman M, Diemar J, O' Connor W, Sushames T, Foulkes L, Nell JA (2000). Development of extended shelf-life microalgae concentrate diets harvested by centrifugation for bivalve mollusks- a summary. Aquacult. Res. 31(8-9): 637-659.

Hernandez JP, De-Bashan LE, Bashan Y (2006). Starvation enhances phosphorus removal from wastewater by the microalga Chlorella spp. co-immobilized with Azospirillum brasilense. Enzyme Microb. Technol. 38: 190-198.

Hirata S, Hayashitani M, Taya M, Tone S (1996). Carbon dioxide fixation in batch culture of Chlorella species using a photobioreactor with a sunlight-collection device. J. Ferment. Bioeng. 81: 470-472.

Hsueh HT, Chu H, Yu ST (2007). A batch study on the bio-fixation of carbon dioxide in the absorbed solution from a chemical wet scrubber by hot spring and marine algae. Chemosphere, 66(5): 878-886.
Hu Q, Sommerfeld M, Jarvis E, Ghirardi M, Posewitz M, Seibert M, Darzins A (2008). Microalgal triacylglycerols as feedstocks for biofuel production: perspectives and advances. The Plant J. 54: 621-639.

Huang GH, Chen F, Wei D, Zhang XW, Chen G (2009). Biodiesel production by microalgal biotechnology. Appl. Energy. 87(1): 38-46.

Huntley ME, Redalje DG (2007). $\mathrm{CO}_{2}$ mitigation and renewable oil from photosynthetic microbes: a new appraisal. Mitigat. Adapt. Strat. Global Change. 12: 573-608.

IIIman AM, Scragg AH, Shales SW (2000). Increase in Chlorella strains calorific values when grown in low nitrogen medium. Enzyme Microb. Technol. 27(8): 631-635.

Jacob-Lopes E, Lacerda LMCF, Franco TT (2008). Biomass production and carbon dioxide fixation by Aphanothece microscopica Nageli in a bubble column photobioreactor. Biochem. Eng. J. 40: 27-34.

Jako C, Kumar A, Wei Y, Zou J, Barton DL, Giblin EM, Covello PS, Taylor DC (2001). Seed-specific overexpression of an Arabidopsis cDNA encoding a diacylglycerol acyltransferase enhances seed oil content and seed weight. Plant Physiol. 126(2): 861-874.

Jimenez C, Cossio BR, Niell FX (2003). Relationship between physicochemical variables and productivity in open ponds for the production of Spirulina: A predictive model of algal yield. Aquaculture, 221: 331-345.

Kadam KL (1997). Power plant flue gas as a source of $\mathrm{CO}_{2}$ for microalgae cultivation: Economic impact of different process options. Energy Convers. Manag. 38: S505-S510.

Kapdan IK, Kargi F (2006). Bio-hydrogen production from waste materials. Enzyme Microbiol. Technol. 38: 569-582.

Khozin-Goldberg I, Cohen Z (2006). The effect of phosphate starvation on the lipid and fatty acid composition of the fresh water eustigmatophyte Monodus subterraneus. Phytochemical, 67: 696701

Knuckey RM, Brown MR, Robert R, Frampton DMF (2006). Production of microalgal concentrates by flocculation and their assessment as aquaculture feeds. Aquac. Eng. 35: 300-313.

Lee JS, Kim DK, Lee JP, Park SC, Koh JH, Cho HS, Kim SW (2002). Effects of $\mathrm{SO}_{2}$ and $\mathrm{NO}$ on growth of Chlorella species KR-1. Bioresour. Biotechnol. 82: 1-4.

Lee RF, Loeblich AR III (1971). Distribution of 21:6 hydrocarbon and its relationship to 22:6 fatty acid in algae. Phytochem. 10: 593-602.

Li Y, Horsman M, Wu N, Lan CQ, Dubois-Calero N (2008). Biofuels from microalgae. Biotechnol. Prog. 24: 815-820.

Miao X, Wu Q (2006). Biodiesel production from heterotrophic microalgal oil. Bioresour. Technol. 97: 841-846.

Mohapatra PK (2006). Biotechnological approaches to microalga culture. In: Textbook of environmental biotechnology. IK International Publishing House Pvt. Ltd, New Delhi, India, pp. 167-200.

Molina Grima E, Belarbi EH, Acien Fernandez FG, Robles Medina A, Chisti Y (2003). Recovery of microalgal biomass and metabolites: process options and economics. Biotechnol. Adv. 20: 491-515.

Muller-Feuga A, Pruvost J, Guedes RL, Dean LL, Legentilhomme P, Legrand J (2003). Swirling flow implementation in a photobioreactor for batch and continuous cultures of Porphyridium cruentum. Biotechnol. Bioeng. 84: 544-551.

Munoz R, Guieysse B (2006). Algal-bacterial processes for the treatment of hazardous contaminants: a review. Water Res. 40: 2799-2815.

Ohlrogge J, Browse J (1995). Lipid biosynthesis. Plant Cell 7: 957-970.

Ono E, Cuello J (2006). Feasibility assessment of microalgal carbon dioxide sequestration technology with photobioreactor and solar collector. Biosystems Eng. 95(4): 597-606.

Otsuka $H$ (1961). Changes of lipid and carbohydrate contents of Chlorella cells during the sulfur starvation, as studied by the technique of synchronous culture. J. Gen. Appl. Microbiol. 7: 72-77.

Parker PL, van Baalen C, Maurer L (1967). Fatty acids in eleven species of blue-green algae: Geochem. Significance Sci. 155: 707708.

Patil V, Reitan KI, Knudsen G, Mortensen L, Kallqvist T, Olsen E, Vogt G, Gislerod HR (2005). Microalgae as source of polyunsaturated fatty acids for aquaculture. Curr. Topics Plant Biol. 6: 57-65.

Patterson G (1970). Effect of temperature on fatty acid composition of Chlorella sorokiniana. Lipids 5: 597-600.

Priya JA, Rao PS, Vijaya Y, Reddy AS, Krishnaiah A (2007). 
Biosorption of chromium (VI), nickel(II) and copper(II) ions from aqueous solutions using Pithophora algae. Toxicol. Environ. Chem. 89: 421-442.

Pulz $\mathrm{O}$ (2001). Photobioreactors: production systems for phototrophic microorganisms. Appl. Microbiol. Biotechnol. 57: 287-293.

Pulz O (2007). Evaluation of greenfuel's 3D matrix algal growth engineering scale unit: APS Red Hawk Unit AZ. IGV Instit. fur Getreidevararbeitung GmbH. June-July, 2007. www.greenfuelonline.com.

Ragauskas AJ, Williams CK, Davison BH, Britovsek G, Cairney J, Eckert CA, Frederick JrWJ, Hallett JP, Leak DJ, Liotta CL, Mielenz JR, Murphy R, Templer R, Tschaplinski T (2006). The path forward for biofuels and biomaterials. Science, 31: 484-489.

Ranga Rao A, Dayananda C, Sarada R, Shamala TR, Ravishankar GA (2007). Effect of salinity on growth of green alga Botryococcus braunii and its constituents. Bioresour. Technol. 98: 560-564.

Reitan KI, Rainuzzo JR, Olsen Y (1994). Effect of nutrient limitation on fatty acid and lipid content of marine microalgae. J. Phycol. 30: $972-$ 979.

Renaud SM, Thinh LV, Lambrinidis G, Parry DL (2002). Effect of temperature on growth, chemical composition and fatty acid composition of tropical Australian microalgae grown in batch cultures. Aquaculture, 211: 195-214.

Richmond A (2003). Handbook of microalgal cultural: Biotechnol. Appl. Phycol. Wiley-Blackwell, Oxford.

Roessler PG (1988). Changes in the activities of various lipid and carbohydrate biosynthetic enzymes in the diatom Cyclotella cryptica in response to silicon deficiency. Arch. Biochem. Biophys. 267: 521 528.

Roessler PG (1990). Purification and characterization of acetyl CoA carboxylase from the diatom Cyclotella cryptica. Plant Physiol. 92: 73-78.

Rossignol N, Vandanjon L, Jaouen P, Quemeneur F (1999). Membrane technology for the continuous separation microalgae/culture medium: compared performances of cross-flow microfiltration and ultrafiltration. Aquacult. Eng. 20: 191-208.

Saha SK, Uma L, Subramanian G (2003). Nitrogen stress induced changes in the marine cyanobacterium Oscillatoria willei BDU 130511. FEMS Microbiol. Ecol. 45: 263-272.

Sanchez Miron A, Garcia Camacho F, Contreras Gomez A, Molina Grima E, Chisti Y (2000). Bubble column and airlift photobioreactors for algal culture. AIChE J. 46: 1872-1887.

Sato N, Hagio M, Wada H, Tsuzuki M (2000). Environmental effects on acidic lipids of thylakoid membranes. In recent advances in the Biochemistry of plant lipids (Harwood $\mathrm{JL}$ and Quinn PJ, eds). Portland Press Ltd, London, pp. 912-914.

Sato T, Usui S, Tsuchiya Y, Konda Y (2006). Invention of outdoor closet type photobioreactor for microalgae. Energy Convers. Manag. 47: 791-799.

Sazdanoff N (2006). Modeling and simulation of the algae to biodiesel fuel cycle. Report, Department of Mechanical Engineering, The Ohio State University, United States.

Schenk PM, Thomas-Hall SR, Stephens E, Marx UC, Mussgnug JH, Posten C, Kruse O, Hankamer B (2008). Second generation biofuels: high-efficiency microalgae for biodiesel production. Bioenerg. Res. 1: 20-43.

Schneider D (2006). Grow your Own? Would the wide spread adoption of biomass-derived transportation fuels really help the environment. American Scientist, 94: 408-409.

Scott A, Bryner M (2006). Alternative fuels: rolling out next-generation technologies. Chemical Week. December 20-27, pp. 17-21.
Scragg AH, Illman AM, Carden A, Shales SW (2002). Growth of microalgae with increased calorific values in a tubular bioreactor. Biomass Bioeng. 23(1): 67-73.

Shastri AA, Morgan JA (2005). Flux balance analysis of photoautotrophic metabolism. Biotechnol. Prog. 21(6): 1617-1626.

Sheehan J, Dunahay T, Benemann J, Roessler P (1998). A look back at the U.S. Department of Energy's Aquatic Species Program- Biodiesel from algae. National Renewable Energy Laboratory, Golden, CO. Report NREL/TP-580-24190.

Shi J, Podola B, Melkonian M (2007). Removal of nitrogen and phosphorus from wastewater using microalgae immobilized on twin layers: an experimental study. J. Appl. Phycol. 19: 417-423.

Shifrin NG, Chisholm SW (1981). Phytoplankton lipids: interspecific differences and effects of nitrate, silicate and light-dark cycles. J. Phycol. 17: 374-384

Singh A, Mehta SK, Gaur JP (2007). Removal of heavy metals from aqueous solution by common freshwater filamentous algae. World $\mathrm{J}$. Microb. Biotechnol. 23: 1115-1120.

Spolaore P, Joannis-Cassan C, Duran E, Isambert A (2006). Commercial applications of microalgae. J. Biosci. Bioeng. 101: 87-96.

Srivastava A, Prasad R (2000). Triglycerides-based diesel fuels. Renew. Sust. Energy Rev. 4: 111-133.

Takagi M, Karseno, Yoshida T (2006). Effect of salt concentration on intracellular accumulation of lipids and triacylglyceride in marine microalgae Dunaliella cells. J. Biosci. Bioeng. 101(3): 223-226.

Tan K, Lee K, Mohamed A, Bhatia S (2009). Palm Oil: addressing issues and towards sustainable development. Renew. Sust. Energy Rev. 13(2): 420-427.

Tornabene TG, Holzer G, Lien S, Burris N (1983). Lipid composition of the nitrogen starved green Neochloris oleabundans. Enzyme Microb. Technol. 5: 435-440.

Tsukahara K, Sawayama S (2005). Liquid fuel production using microalgae. J. Japan Petrol. Instit. 48: 251-259.

Usui N, Ikenouchi M (1997). The biological $\mathrm{CO}_{2}$ fixation and utilization project by RITE (1)- highly-effective photobioreactor system. Energy Convers. Manag. 38(1): S487-S492.

Xiong W, Li X, Xiang J, Wu Q (2008). High-density fermentation of microalga Chlorella protothecoides in bioreactor for microbiodiesel production. Appl. Microbiol. Biotechnol. 78: 29-36.

Yun YS, Lee SB, Park JM, Lee CI, Yang JW (1997). Carbon dioxide fixation by algal cultivation using wastewater nutrients. J. Chem. Technol. Biotechnol. 69: 451-455.

Zhila NO, Kalacheva GS, Volova TG (2005). Effect of nitrogen limitation on the growth and lipid composition of the green alga Botrycoccus braunii Kutz IPPAS H-252. Russ. J. Plant Physiol. 52: 357-365. 